\title{
Disfigurement: Perceived and Actual
}

On 27 March 1987, the Liaison Group of the Royal College of Psychiatrists and the Society for Psychosomatic Research held a joint conference on 'Disfigurement: Perceived and Actual' at the Royal College of Psychiatrists. It was the first collaborative venture between the uni-disciplinary Liaison Group and the multi-disciplinary Society, but it is hoped it will be the first of a productive series. The Conference was well attended. The morning presentations were concerned mostly with dysmorphophobia, and the afternoon's with unmistakable disfigurement. The proceedings ended with a presentation, by Mrs Christine Piff, on her own experiences following surgery for facial cancer, and with her prosthesis. It is reproduced below.

Every day there are a large number of people who suffer irrevocable damage to their faces. The most common cause of injury comes from road accidents, but burns and surgery are also responsible. Sophisticated technology can save people who otherwise might have died and can rehabilitate looks with micro surgery. But it is at this point of apparent success that a whole new set of problems begins.

However the face is damaged, the pain and distress to the person concerned and the disturbing effect on family and friends is incalculable. The experience of not being able to communicate as we used to; of losing the ability to express our emotions, is something none of us can prepare for, or understand, until it happens to us, or someone we love.

The resulting feeling of rejection and isolation can cause serious psychological problems not helped by the continuing demand of treatment and daily contact with other people, however well intentioned. It is understandable that you don't see many people with spoiled looks around. Their confidence is shaken, many shut themselves away, remaining cut off from society.

Ten years ago, I underwent surgery to remove a tumour from my sinus. I was left with half a face, and a battle to survive that took every ounce of my strength, my husband's, my children and other family and friends. The effort to try to gain normality after hospital was superhuman. It took seven years of fighting before I came to accept my 'changed' face but in accepting it, I accepted life again.

I could never come to terms with my 'new face'. How could anyone expect you to? To look in a mirror and see the mutilation of my face, the hole in my face where my cheek and eye used to be. Half a palate, no teeth. No one can understand how you feel, not even the surgeon who saved your life can imagine what it is like to carry on. The only people who understand are the people who have been through it, who have experienced a 'changed face'. These are the people who taught me to accept my new looks and be grateful for them.

In January 1984, I took part in a television programme made for Channel 4 and during the programme I launched our Support Network for the facially disfigured. I was unaware how many people underwent surgery to their faces, but I soon realised there were hundreds. Within two months I had received over 600 letters from people suffering from congenital disfigurement, car accidents, burns, Bell's palsy, acne and cancer. None of these friends had received counselling or support.

The Network does not have members as such, we are all good friends. It has been growing now for three years, and has progressed to South Africa and Boston, USA. We have regional meetings all over the country, where friends in the Network meet their families and friends in a hospital where they are familiar with staff. The professionals are giving their support, and encouraging new patients to meet.

Initially, new patients admitted to hospital are not interested in a LFI Group. They are too involved in their cancer or surgery to consider counselling. However, some patients meet me prior to surgery and are able to ask about problems that may arise. It is the families who need support and understanding more than the patient at this time. They need to know that their loved one is going to be the same after surgery.

I reassure them that surgery does not change them. We are still the same people inside but if you treat us differently we will behave differently. What we need is to be loved and cared for, to be treated with respect and dignity. The lack of privacy and care in hospital can destroy self esteem and confidence, making the fight back to normal even more difficult.

The period of time for the patient when sent home from hospital is the toughest of all. The deep psychological problems that occur cause anguish and pain to the patient and to the family. It is at this stage that a friend is needed to help the patient get through this bereavement. I make myself available seven days a week, 24 hours a day, for friends in need of an understanding ear to listen; we cry together and then laugh with each other.

That is what the Network is for. To offer love, care and support for all facially disfigured people. The friends that I have made over the past three years cannot be measured as compensation for my face. What I have gained is the ability to accept it. No single person can help us, we need to help ourselves and each other. In helping each other we as individuals grow and learn to be thankful for the faces we now have.

Let's Face It

Christine PifF

Network for the Facially Disfigured

10 Wood End, Crowthorne, Berks RG11 6DQ 